\title{
THE EFFECT OF BRAND THRUST ON FINANCIAL PERFORMANCE OF PROPERTY COMPANIES IN INDONESIA CAPITAL MARKET
}

\author{
Njo Anastasia ${ }^{* 1}$ and Dewi Pricilia Sari**) \\ *) Finance Program, Faculty of Business and Economics, Petra Christian University \\ Jl. Siwalankerto 121-131, Surabaya 60236, Indonesia \\ **) Graduate Institute of Finance, National Taiwan University of Science and Technology \\ No. 43, Section 4, Keelung Rd., Da'an District, Taipei City, Taiwan
}

\begin{abstract}
The rapid economic growth and development encourage companies to have sustainable competitive advantage in order to compete in the market. One of the strategies to face this competition is building a good brand image. Brand has always been an important factor in company's growth. The concept of brand thrust was used to show the level of company allocation to enhance their brand image. This study aims to examine the effect of brand thrust on financial performance of property companies in Indonesia capital market for the period 2009-2016. The independent variables used are brand thrust and firm characteristics. The dependent variable used is financial performance. The method used is panel data Ordinary Least Square (OLS) regression with the number of sample are 28 firms of property sector. This study reveals brand thrust, long term debt to assets ratio, stock market beta, market share, operating profit margins, and capital expenditure to property, plant, and equipment have a significant influence on financial performance of property companies.
\end{abstract}

Keywords: brand thrust, firm characteristics, financial performance, property sector, OLS

\begin{abstract}
Abstrak: Pertumbuhan dan perkembangan ekonomi yang pesat mendorong perusahaan untuk memiliki keunggulan kompetitif yang berkelanjutan pada persaingan pasar. Salah satu strategi untuk menghadapi persaingan adalah membangun brand yang baik. Brand menjadi faktor penting untuk pertumbuhan perusahaan. Konsep brand thrust digunakan untuk menunjukkan tingkat alokasi perusahaan dalam meningkatkan citra mereknya. Penelitian ini bertujuan menguji pengaruh brand thrust terhadap kinerja keuangan perusahaan properti di Pasar Modal Indonesia untuk periode 2009-2016. Variabel independen yang digunakan adalah brand thrust dan karakteristik perusahaan. Variabel dependen yang digunakan adalah kinerja keuangan. Metode yang digunakan adalah data panel regresi Ordinary Least Square (OLS) dengan jumlah sampel 28 perusahaan sektor properti. Penelitian ini mengungkapkan brand thrust, rasio hutang jangka panjang terhadap aset, beta pasar, pangsa pasar, marjin laba operasional, dan pengeluaran modal untuk properti, mesin, dan peralatan berpengaruh signifikan terhadap kinerja keuangan perusahaan properti.
\end{abstract}

Kata kunci: brand thrust, karakteristik perusahaan, kinerja keuangan, sektor properti, $O L S$

${ }^{1}$ Corresponding author:

Email: anas@petra.ac.id 


\section{INTRODUCTION}

This rapid economic growth and development have led to increasingly tight competition among companies. Every company requires to create a sustainable competitive advantage to compete, especially with those engaged in the same industry. This intense competition encourages companies to have a strategy to maintain their market share. Brands are useful to differentiate one company from another in market competition (Leitch \& Davenport, 2007). At this moment, Indonesian people are more concerned with brands than consumers of other countries (Budiman et al. 2013). According to Thoma \& Williams (2013), as well as Hasan et al. (2012), in the purchasing process, consumers are more likely to buy products with better known brands, so brands become a priority of consumer purchase preferences, not the product. This is because consumers do not consider the importance of product specifications and manufacturing processes. The products or services that are produced tend to be similar, so consumers are more likely to choose products with brands that are more famous or trusted. The second thing is the feeling of pride gained by consumers. This condition can also happen to property buyers that the property developed by certain brands.

Aaker (1992) and Hsu et al. (2013) stated that brands are intangible assets of companies that has an economic value and create competitive advantages that are important for future corporate earnings and can increase the wealth of the company's shareholders. Increased brand awareness and brand loyalty will be followed by an increase in trust and intensity of purchases, which will have an impact on improving the company's financial performance. Brand awareness and brand loyalty are aspects of brand equity which are important in a brand, because both aspects have an impact on company profits. Consumer loyalty can project estimate sales and profits obtained by the company. Consumer satisfaction can be an indicator of a good brand and can serve as a reference to continue to develop brand power (Aaker, 1992). According to Ourusoff et al. (1992), currently most companies does not hesitate to spend extraordinary costs to create success by developing a good brand. It is noted that on average $3 \%-5 \%$ of the company's turnover is aimed at branding. In addition, several studies also show that a positive correlation between the quality of a good brand tends to generate higher corporate profits .
Barth et al. (1998) research shows that the value of a brand is influenced by the amount of costs and sacrifices incurred by the company. Brand thrust is defined as the total financial resources a company allocates to develop, build and maintain the values and signals of its brand(s) including marketing activities and emotional features, with its products or services and its combined efforts in representing and distributing its bundle of goods and services to its constituency, over a defined period of time (Ohnemus \& Jenster, 2008). The increase in costs incurred by companies that is related to branding aims to increase sales in the future where these costs are also associated with all matters relating to the company's marketing strategy (Narasimhan et al. 2006). Brand thrust is an investment which include all of the activities of a company that aims to improve the image of a brand, so that investment can also be an attraction for investors in determining the company's financial performance. In the property and real estate sector in Indonesia, having a good brand image is one of the company's advantages. Today, many companies implement pre-selling systems.

Conchar (2005) study states that the expenditure allocated to creating a company's brand can be calculated using Advertising and Promotion expense. Collins \& Han (2004) explained that the company's advertising costs are calculated using selling, general and administrative costs. Coate \& Uri (1986) in their research also said that branding costs can be calculated using only advertising expense or can also be calculated using total selling expense depending on the level of profitability and elasticity of the company's costs. The total selling expense shows all costs associated with branding and all costs associated with the company's marketing activities include advertising and promotions, exhibitions, sales commissions, and others. According to the results of Chatterjee \& Chaudhuri's study (2005) the proper allocation of branding costs can increase consumer confidence in a company's brand and have a positive impact on increasing the value of the company's stock and market competitive position.

The concept of brand thrust is a new concept initiated by Ohnemus \& Jenster (2008) to show that a brand describes a close and interconnected relationship between finance and marketing, especially when associated with the property sector in Indonesia where property sector companies in Indonesia are use preselling systems in selling the property. Hence, it requires a substantial funds to carry out promotional activities. 
This system is an effective strategy and used by many property developers in Indonesia because it has minimal risk but effective to increase property demand with the lure of many benefits, such as lower prices and priority in unit selection, so that some property developers are competing to use this strategy to increase sales (Bayu, 2015). This system represents current buying behavior of the Indonesian people who are concerned with brands, where companies that use this system are required to have the credibility of a good brand. Buyers also receive benefits, developers who have good credibility will personally increase the pride of buyers for the ownership of property assets that they buy.

A good brand will affect customer satisfaction. Consumer satisfaction is one of the fundamental factors of company performance in the past, present, and future where the level of customer satisfaction will affect the level of investment in branding by companies (Anderson et al. 1994). The higher the level of customer satisfaction, indicates the higher the level of consumer loyalty to the brand. It can reduce the elasticity of price level, reduce costs to create new consumers and improve the company's reputation that has an impact on profitability of company. It can be said that customer satisfaction plays an important part in building company assets which is brand, among many other (Aaker, 1992).

Ohnemus \& Jenster (2008) stated that there is a correlation between brand thrust and financial performance or financial returns of a company shown with return on assets and market to book ratio. In that study, a total of 2158 companies surveyed from various sectors in continental Europe and the United States showed there is a correlation between brand thrust and financial performance (measured by return on asset (ROA) and market to book ratio (M/B) with 5 Phases W Curve (Curve W). This curve illustrates 5 phases of development of branding investment approach of company. The companies who use brand thrust with a balanced and good strategy will generate returns to shareholders 3\% higher than other companies in the same industry. Liow \& Sim (2006) also shows that the most significant indicator of determining the level of performance of a property sector are Return on Assets and Market to Book Ratio. Return on Assets will show the level of profitability of the company, while Market to Book Ratio will show the company's market value from the investor's perspective.
Kerin \& Sethuraman (1998) used a sample of companies included in "most valued brands" also claims and that companies in this category had a positive relationship between brand and M/B ratio. Barth et al. (1998) also revealed the results of their research where the higher the value of a brand, the more significant the impact on prices and stock returns, positively. The amount of brand thrust allocated by the company has a positive impact to the company's market value, where there is a mutually supportive relationship between the company's activities to build its brand and the company's financial performance. According to Crass, et al. (2016) brands affect the level of profitability of the company. Companies that focus on developing their brands consistently can generate growth, profitability and gain long term returns. Shipley \& Howard (1993) said that most companies believes that a good brand is one of the contributing factor in the company's success. Therefore, current brand thrust is considered to be an investment, where a stable brand thrust and with the right strategy can create more profits for the company (Conchar, 2005).

On the other side, the company expenditure for branding are an investment because brand is one of the company's assets. Branding can create debt for companies. The higher level of debt used, the higher probability of debt risk that is difficult to estimate and has a negative impact to the company profitability. This solvency ratio is very relevant to property sector companies where many of their assets are financed by debt (Fama \& French, 1992). This is in accordance with the W Function theory, the higher the additional cost of brand thrust is used, without a good strategy will reduce the company's financial performance where this will be indicated by a high solvency ratio and also called overbranding.

This research is a development of Ohnemus \& Jenster (2008) research with a focus on more specific sectors, property sector. Successful property sector companies generally obtain market value that are more attractive than their book value, as well as higher profitability will contribute to the company's long term sustainable growth. This study will analyze the effect of brand thrust influence to financial performance of property sector companies in Indonesia. This research will be useful for investors who are interested in property stocks, taking into account the brands built by property companies that affect the value of the company through financial performance. 


\section{METHODS}

Data used in this research are secondary data acquired through annual report from property sector companies in Indonesia which were obtained from the website idx.co.id. Purposive sampling is used to choose the criteria sample such as: The company has been listed in Indonesia Stock Exchange and Initial Public Offering (IPO) since 2019; The company publishes the complete financial annual report (reported total selling expense) during the period of year 2009 to 2016.

Variables that are used in the study are divided into dependent variables and independent variables (see Table 1). The dependent variable used is the company's financial performance which is measured using return on assets (ROA) and market to book ratio (M/B). The independent variables used are divided into two (2), brand thrust and firm characteristics. Brand thrust as measured by total selling expense (TSE). The firm characteristics as the control variable are grouped in structure, market, and company performance. First, Long term debt to asset ratio (LDAR) and capital expenditure to property, plant, and equipment (CAPEX). Both of these ratios represent the corporate structure that describes the company's ability to pay off liabilities or leverage associated with the company's capital structure (Subiantoro \& Mildawati, 2015; Rizki et al. 2019).

The next firm characteristics variables is the company's market performance as measured by market share (MS) and stock market beta (BETA). The market ratio of a company fluctuates with the number of investors and opportunities that the company has. Ohnemus \& Jenster (2008) said that brands which have a strong competitive position in the market become effective barriers for competitors, is able to easily attract the attention of consumers, and have the ability to offer higher prices. Market value is one of the tools to determine the condition of a company's financial performance. The greater the company's stock beta value means the greater the company's systematic risk which leads to decrease investor's interest and has an impact in reducing the company's market value. Therefore, companies must have strategies to be able to compete in market to obtain investor's interest, one of them is branding strategy. Kerin \& Sethuraman (1998) and Barth et al. (1998) stated that an increase in branding efforts by a company has a significant positive relationship to price and stock returns. Therefore, the intensity of branding carried out by property companies has a direct impact on market reaction. The last firm characteristics variable describes the company's performance in obtaining profit from the activities conducted by the company as measured by operating profit margin (OPM). One of its activities is company's investment on brand. Branding is one of the investments made by the company to increase brand awareness.

H1: Brand thrust and firm characteristics have a significant effect on financial performance in property sector.

This research uses panel Ordinary Least Square (OLS) regression technique because the data consist of cross section and time series data. Model to study the effect of brand thrust to financial performance in property companies:

Model 1:

$\mathrm{ROA}=\beta_{0}+\beta_{1} \mathrm{TSE}_{\mathrm{it}}+\beta_{2} \mathrm{LDAR}_{\mathrm{it}}+\beta_{3} \mathrm{BETA}_{\mathrm{it}}+\beta_{4} \mathrm{MS}_{\mathrm{it}}+$ $\beta_{5} \mathrm{OPM}_{\mathrm{it}}+\beta_{6} \mathrm{CAPEX}_{\mathrm{it}}+\mathrm{e}_{\mathrm{it}}$

Model 2:

$\mathrm{M} / \mathrm{B}=\beta_{0}+\beta_{1} \mathrm{TSE}_{\mathrm{it}}+\beta_{2} \mathrm{LDAR}_{\mathrm{it}}+\beta_{3} \mathrm{BETA}_{\mathrm{it}}+\beta_{4} \mathrm{MS}_{\mathrm{it}}+$ $\beta_{5} \mathrm{OPM}_{\mathrm{it}}+\beta_{6} \mathrm{CAPEX}_{\mathrm{it}}+\mathrm{e}_{\mathrm{it}}$

\section{RESULTS}

\section{Descriptive statistics}

The descriptions of data related to 28 firms of property sector that have passed the sampling criteria in the period 2009-2016 are shown in Table 2. This company study showed a variety of ROA, corporate beta market, OPM and CAPEX, fluctuating between negative and positive values. Total selling expense and market share is stable and there is not too much of a difference between companies. Then, this study uses panel data analysis because the data are taken from different cross sections and time series. The random effect model can be used in this panel data regression because this model pass from Chow test and Hausman test. The findings of this research are provided in Table 3. 
Table 1. Measurement of the dependent and independent variables

\begin{tabular}{|c|c|c|}
\hline Variable & Definition & Measurement \\
\hline \multicolumn{3}{|l|}{ Dependent Variable } \\
\hline Return on Asset (ROA) & $\begin{array}{l}\text { A ratio that shows the effectiveness of a company to } \\
\text { generate returns from assets used }\end{array}$ & Net income divided by total assets \\
\hline $\begin{array}{l}\text { Market to Book Ratio } \\
(\mathrm{M} / \mathrm{B})\end{array}$ & $\begin{array}{l}\text { A ratio used to evaluate the current market value of } \\
\text { the company against the value of the book }\end{array}$ & $\begin{array}{l}\text { Market capitalisation divided by total } \\
\text { book value }\end{array}$ \\
\hline \multicolumn{3}{|l|}{ Independent Variable } \\
\hline $\begin{array}{l}\text { Total Selling Expense } \\
(\mathrm{TSE})=\text { Brand Thrust }\end{array}$ & $\begin{array}{l}\text { A value that shows all costs associated with } \\
\text { branding and all costs associated with the company's } \\
\text { marketing activities include the costs of advertising } \\
\text { and promotions, exhibitions, sales commissions, and } \\
\text { others }\end{array}$ & Total selling expense divided by sales \\
\hline $\begin{array}{l}\text { Long Term Debt to Asset } \\
\text { Ratio (LDAR) }\end{array}$ & $\begin{array}{l}\text { One of the solvency ratios which calculates the } \\
\text { percentage of companies funding their assets }\end{array}$ & Long term debt to total assets \\
\hline Stock Market Beta (Beta) & $\begin{array}{l}\text { Systematic risk measure and company performance } \\
\text { measure }\end{array}$ & $\begin{array}{l}\text { The sum of covariance of stock and } \\
\text { market divided by variance of market }\end{array}$ \\
\hline Market Share (MS) & $\begin{array}{l}\text { Percentage of market sales obtained by company over } \\
\text { a certain period }\end{array}$ & $\begin{array}{l}\text { Firm sales divided by total sales in } \\
\text { firm industry }\end{array}$ \\
\hline $\begin{array}{l}\text { Operating Profit Margin } \\
\text { (OPM) }\end{array}$ & $\begin{array}{l}\text { A ratio that measures the overall effectiveness of } \\
\text { company's operational }\end{array}$ & Operating income divided by sales \\
\hline $\begin{array}{l}\text { Capital Expenditure } \\
\text { to Property, Plant, and } \\
\text { Equipment (CAPEX) }\end{array}$ & $\begin{array}{l}\text { A value that shows the intensity of capital of a } \\
\text { company }\end{array}$ & $\begin{array}{l}\text { Capital expenditure to net property, } \\
\text { plant, and equipment }\end{array}$ \\
\hline
\end{tabular}

Table 2. Statistic descriptive

\begin{tabular}{lccccc}
\hline & Mean & Median & Maximum & Minimum & Std. Dev \\
\hline ROA & 0.055 & 0.043 & 0.359 & -0.083 & 0.058 \\
M/B & 1.557 & 1.166 & 7.534 & 0.092 & 1.291 \\
TSE & 0.044 & 0.040 & 0.180 & 0.001 & 0.028 \\
LDAR & 0.400 & 0.419 & 0.786 & 0.008 & 0.174 \\
BETA & 0.697 & 0.728 & 4.445 & -5.990 & 1.103 \\
MS & 0.032 & 0.018 & 0.196 & 0.000 & 0.038 \\
OPM & 0.271 & 0.267 & 1.382 & -0.613 & 0.222 \\
CAPEX & 0.460 & 0.504 & 1.659 & -1.578 & 0.510 \\
\hline
\end{tabular}

Table 3. Random effect model regression results

\begin{tabular}{lcccc}
\hline & \multicolumn{2}{c}{ Model 1 } & \multicolumn{2}{c}{ Model 2 } \\
\hline & \multicolumn{2}{c}{ Return on Asset } & \multicolumn{2}{c}{ Market to Book Ratio } \\
\hline Intercept & Coef. & t-Stat & Coef. & t-Stat \\
Total Selling Expense & 0.004 & 0.347 & 1.492 & 4.824 \\
Long Term Debt to Assets Ratio & -0.141 & -1.210 & -11.564 & $-3.635^{* * *}$ \\
Stock Market Beta & 0.024 & 1.273 & 1.236 & $2.306^{* *}$ \\
Market Share & -0.005 & $-1.945^{* *}$ & -0.176 & $-1.843^{*}$ \\
Operating Profit Margin & 0.129 & 1.397 & 3.536 & $1.869^{*}$ \\
Capex to Prop. Plant, and Equipment & 0.179 & $13.916^{* * *}$ & 1.016 & $1.853^{*}$ \\
\hline Adjusted R2 & -0.003 & -0.049 & -0.391 & $-1.905^{*}$ \\
F-Statistic & 0.478 & & 0.143 & $7.219^{* * *}$ \\
\hline Note: $*$ p-value $<10 \%, * *$ p-value $<5 \%$ and $* * *$ & &
\end{tabular}

Note: ${ }^{*}$ p-value $<10 \%, * *$ p-value $<5 \%$, and $* * *$ p-value $<1 \%$ 


\section{The Effect of Brand Thrust on Financial Performance}

The results shows that brand thrust does not have a significant effect to ROA of property sector companies in Indonesia. Using ROA for measuring financial performance is inappropriate, because ROA only focus on short term or current sales value. Prior research by Srivastava et al. (2005) also stated that allocation of branding or brand thrust costs can provide a negative return on the company because branding is one of the long term investments. These results indicate that the higher the cost of brand thrust allocated, the lower the company's ROA is. The second analysis, brand thrust has a significant influence and negatively related to the market to book ratio (M/B). Merino's (2004) found that one of the financial performance measurement ratios that can reflect future or long term impacts on a company's intangible assets is $\mathrm{M} / \mathrm{B}$. The higher the level of investment allocated to brand thrust, the lower the the company's market value will be, thus leading to a decrease on the value of $\mathrm{M} / \mathrm{B}$. The company expands its branding activities by increasing brand thrust with the aim of obtaining a higher market value, but consumers might not be aware of the additional expenditures made by the company, resulting in a negative reaction which is in accordance with the W Function theory. This is called over branding, because the property companies has been going public for more than 8 years. The brand was certainly well known by the public, and investors saw this as an unimportant excessive investment, which leads to a negative response about branding.

\section{The Effect of Firm Characteristic to Financial Performance}

Firm characteristics measured by long term debt to asset ratio (LDAR), market share (MS), and capital expenditure to property, plant, and equipment (CAPEX) do not have a significant effect to financial performance measured using ROA, but has a significant effect on $\mathrm{M} / \mathrm{B}$. This shows that the property and real estate sector companies are financed by their own capital $(60 \%$ $-80 \%$ ) so they do not depend on long term debt as the funding. The strategy of pre-selling sales changed the financing pattern of property sector companies in Indonesia, where the capital is financed by the down payment of the product. Due to changes in this funding pattern, it reduces the risk of bankruptcy and ultimately increasing company value (Efni et al. 2012). In addition to funding factors, the influence of "word of mouth' marketing strategies also affect the company's branding activities where this strategy does not require capital, but can be more effective in increasing the expectations and perceptions of consumers (Armelini \& Villanueva, 2010). This research show that LDAR does not influence on ROA, but LDAR influeces M/B. Dae (2015) research also stated that increasing in debt will be beneficial when it has reached a certain optimal point. In accordance with the Signaling and Model Theory of Asymmetric Information developed by Barclay et al. (1995), companies with large leverage can be used by managers as an optimistic signal of the company's future. This theory is based on the idea that managers who have good information about the company will try to convey the information to investors which can lead to the company's stock price to increase. Furthermore, the company spends its capital on fixed assets and hope to increase values of sales, so company's market share also increases. However, this strategy cannot increase company ROA. Tortoriello (2008) reported that a high CAPEX will cause a low rate of return. In the long term, CAPEX have a significant effect on $\mathrm{M} / \mathrm{B}$. This ratio serves to show how big of an intensity a company's capital is to its assets. Property sector companies certainly have a large amount of assets where the assets are financed by capital expenditure. High cost of capital issued without the right strategy in sales will affect the company's financial performance.

This study shows the indicator of firm characteristics are stock market beta and OPM have a significant effect on ROA and M/B. The higher the beta stock shows the higher level of systematic risk of company, and the higher risk of stock. It can lead to decreasing investor's interest in company's shares. The OPM significantly affect to ROA positively. OPM is a ratio that describes net profit of company and effectiveness of company's operational performance, so the higher this ratio is the better it is to a company's performance in increasing its income. The higher the income earned by the company, the higher the company profitability (ROA) will also be. According to d'Amato's research (2015) in the property sector, one of the company's main sources of income is derived from Net Operating Income. Kusuma et al. (2012) also showed OPM of property sector in Indonesia has a significant positive effect on financial performance. This research also stated that OPM has a significant effect to $\mathrm{M} / \mathrm{B}$. This indicates that stock value of property sector is not only affected by the amount of debt, but it is also affected by operational cost such as branding cost, which describes the level 
of company's risk. The magnitude of branding cost describes the direct perception of community regarding the company's financial performance regardless of the level of effectiveness company operations.

\section{Managerial Implications}

According to the results, managers can establish strategies that can link the characteristics of the company (capital structure, market, company performance) with the financial performance related to brand thrust. The costs incurred to build a brand are long-term investments, so careful planning related to financial management is needed, especially in property-sector companies. A good brand will improve the image of the developer and in the long run will increase the value of the company.

\section{CONCLUSIONS AND RECOMMENDATIONS}

\section{Conclusions}

This research concludes that brand thrust influences the financial performance, especially market to book ratio. Specifically, that brand thrust and long term debt to asset ratio have a significant effect on market to book ratio. Furthermore, operating profit margin also have a significant effect on return on assets. the other result also show that capital expenditure to Property, Plant, and Equipment (PPE) and market share does not significantly affect return on assets and market to book ratio.

\section{Recommendations}

This research has a few limits, which constitutes areas for future research. First, the next researcher who is interested in Brand Thrust topic, can divide the company according to property types which are residential, commercial, industrial, and specific objectives in order to see the effect of brand thrust on the financial performance in property sector more specifically. Second, next researcher can add variables regarding the uniqueness of property sector funding companies such as down payment. Third, the firm characteristics can be positioned as a control variable in order to see the influence of brand thrust on financial performance in property sector more critically.

\section{REFERENCES}

Aaker DA. 1992. The value of brand equity. Journal of Business Strategy 13(4):27-32.

Anderson EW, Fornell C, Lehmann DR. 1994. Customer satisfaction, market share, and profitability: Findings from Sweden. Journal of Marketing 58(3):53-66.

Armelini G, Villanueva J. 2010. Marketing expenditures and word-of-mouth communication: Complements or substitutes?. Foundations and Trends in Marketing 5(1):1-53.

Barclay MJ, Smith CW, Watts RL. 1995. The determinants of corporate leverage and dividend policies. Journal of Applied Corporate Finance 7(4):4-20.

Barth ME, Clement MB, Foster G, Kasznik R. 1998. Brand Values and Capital Market Valuation. Review of Accounting Studies 3: 41-68.

Bayu DJ. 2015. NUP, Cara jitu merayu konsumen.http://properti.kompas.com/ $\mathrm{read} / 2015 / 03 / 29 / 140000121 / \mathrm{NUP}$.Cara.Jitu. Merayu.Konsumen.

Budiman A, Chhor H, Razdan R. 2013. Understanding the Diversity of Indonesia's Consumers. McKinsey Quarterly, McKinsey \& Company, April.

Chatterjee SC, Chaudhuri A. 2005. Are trusted brands important?. The Marketing Management Journal 15(1):1-16.

Coate MB, Uri N. 1986. A simultaneous equations model of profitability concentration and marketing expense. Journal of Behavioral Economics 15(3):1-15.

Collins CJ, Han J. 2004. Exploring applicant pool quantity and quality: the effects of early recruitment practice strategies, corporate advertising, and firm reputation. Personnel Psychology 7:685-717.

Conchar MP. 2005. Market valuation models of the effect of advertising and promotional spending: A review and meta-analysis. Journal of the Academy of Marketing Science 33(4):445-460.

Crass D, Czarnitzki D, Toole AA. 2016. The dynamic relationship between investments in brand equity and firm profitability: Evidence using trademark registrations. USPTO Economic Working Paper 2016-1:1-32.

d'Amato M. 2015. Income approach and property market cycle. International Journal of Strategic Property Management 19(3):207-219. 
Dae CN. 2015. Pengaruh faktor internal dan eksternal dalam nilai perusahaan pada perusahaan manufaktur yang terdaftar di bursa efek Indonesia (BEI). Artikel Ilmiah, pp. 1-17.

Efni Y, Hadiwidjojo D, Salim U, Rahayu M. 2012. Keputusan investasi, keputusan pendanaan dan kebijakan deviden: Pengaruhnya terhadap nilai perusahaan. Jurnal Aplikasi Manajemen 10(1):128-141.

Fama EF, French KR. 1992. The cross section of expected stock returns. The Journal of Finance 47(2):427-465.

Hasan SA, Subhani MI, Osman A. 2012. A battle between branded and me too brands (unbranded) products, s.1.: MPRA Paper No.35677.

Hsu FJ, Wang TY, Chen MY. 2013. The impact of brand value on financial performance. Advances in Management and Applied Economics 3(6):129141.

Kerin RA, Sethuraman R. 1998. Exploring the brand value-shareholder value nexus for consumer goods companies. Journal of the Academy of Marketing Science 26(4):260-273.

Kusuma GI, Suhadak, Arifin Z. 2012. Analisis pengaruh profitabilitas (profitability) dan tingkat pertumbuhan (growth) terhadap struktur modal dan nilai perusahaan (Studi pada perusahaan real estate and property yang terdaftar di Bursa Efek Indonesia (BEI) periode 207-2011. e-Journal Fakultas Ilmu Administrasi Universitas Brawijaya Malang 7(2):1-15.

Leitch S, Davenport S. 2007. Corporate brands and social brands: Co-branding GM-Free and UK Supermarkets. International Studies of Management \& Organisation 37(4): 45-63.

Liow KH, Sim MC. 2006. The risk and return profile of Asian Real Estate Stocks. Pacific Rim Property Research Journal 12(3):283-310.

Merino MC. 2004. The Role of Market Based Assets in Reducing Corporate Risk.. s.1.:Unpublished dissertation the Faculty of the Graduate School of The University of Texas at Austin.

Narasimhan O, Rajiv S, Dutta S. 2006. Absorptive capacity in high technology markets: The competitive advantage of the haves. Marketing Science 25(5):510-524.

Ohnemus L, Jenster PV. 2008. Corporate brand thrust and financial performance: An examination of strategic brand investments. International Studies of Management \& Organization 37(4):84-107.

Ourusoff A, Ozanian M, Brown PB, Starr J. 1992. What's in a name? What the world's top brands are worth. Financial World 1:32-49.

Rizki A, Anggraeni L, Hardiyanto AT. 2019. Significant impact of working capital and macroeconomic condition on profitability in property industry. Jurnal Aplikasi Manajemen dan Bisnis 5(1):121130.

Shipley D, Howard P. 1993. Brand-naming industrial products. Industrial Marketing Management 22(1):59-66.

Srivastava R, Reibstein DJ, Joshi YV. 2005. Lingking marketing metrics to financial performance, s.1.: ZIBS Technical Report, Zyman Institute of Brand Science, Goizueta Business School at Emory University.

Subiantoro OH, Mildawati T. 2015. Pengaruh karakteristik perusahaan terhadap pengungkapan corporate social responsibility. Jurnal Ilmu \& Riset Akuntansi 4(9): 1-21.

Thoma V,Williams A. 2013. The devil you know: The effect of brand recognition and product ratings on consumer choice. Judgement and Decision Making 8(1):34-44.

Tortoriello R. 2008. Quantitative Strategies for Achieving Alpha: The Standard and Poor's Approach to Testing Your Investment Choices. 1st ed. ed. New York: McGraw Hill Finance \& Investing. 